\title{
The Effect of Seasonal Variation on Rosmarinus officinalis (L.) Essential Oil Composition
}

\author{
Emel Dıraz Yıldırım* \\ Department of Biology, Faculty of Arts and Science, Kahramanmaraş Sütçü İmam University, Kahramanmaraş, Turkey
}

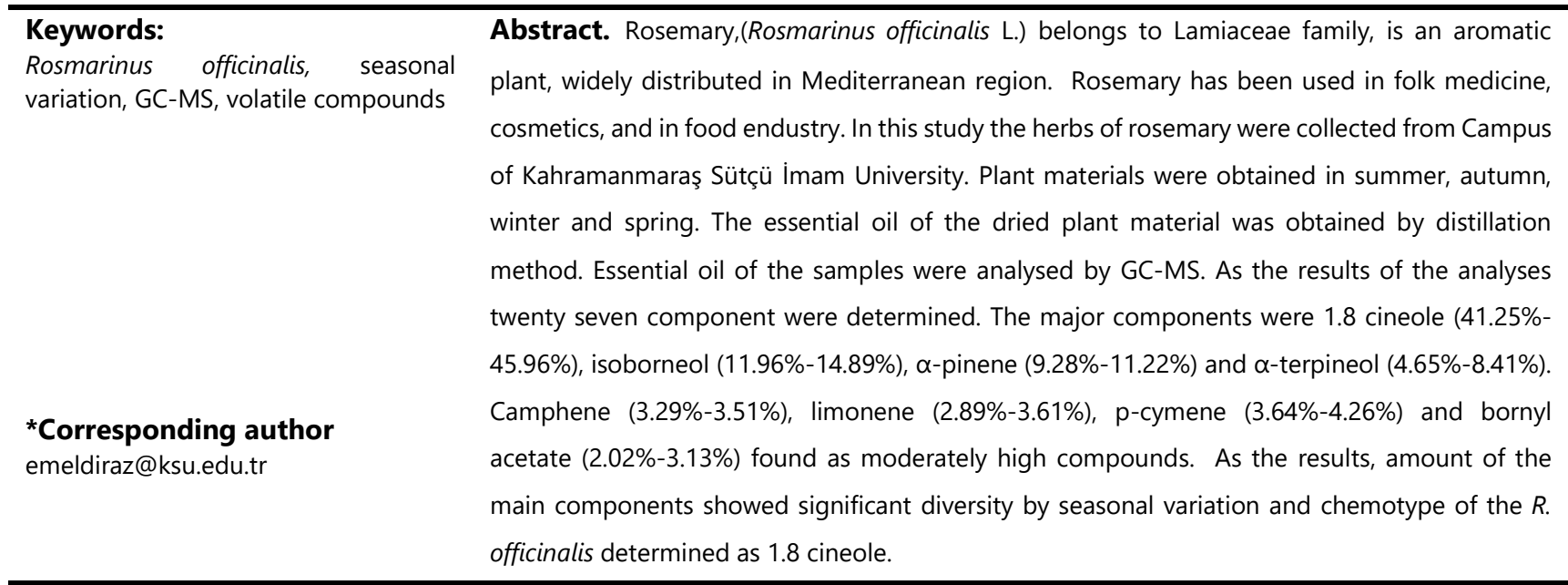

\section{Mevsimsel Varyasyonun Rosmarinus officinalis (L.) Uçucu Yağ Bileşenlerine Etkisi}

\begin{tabular}{|c|c|}
\hline $\begin{array}{l}\text { Anahtar kelimeler: } \\
\text { Rosmarinus officinalis, mevsimsel } \\
\text { varyason, GC-MS, uçucu bileşen }\end{array}$ & $\begin{array}{l}\text { Özet. Biberiye (Rosmarinus officinalis L.) Lamiaceae familyasına ait olup, Akdeniz Bölgesi'nde } \\
\text { yaygın olarak bulunan aromatik bir bitkidir. Biberiye, halk tıbbında, kozmetikte ve gıda } \\
\text { endüstrisinde kullanılmaktadır. Bu çalışmada biberiyenin topraküstü kısımları Kahramanmaraş } \\
\text { Sütçü İmam Üniversitesi Kampüsü'nden yaz, sonbahar, kış ve ilkbahar mevsimlerinde } \\
\text { toplanmıştır. Kurutulmuş bitki materyallerinin uçucu yağları distilasyon metodu ile elde edilmiştir. } \\
\text { Uçucu yağlar GC-MS cihazı ile analiz edilmiştir. Analiz sonuçlarına göre yirmi yedi bileşen tespit } \\
\text { edilmiştir. Ana bileşenler } 1.8 \text { sineol (\%41.25-\%45.96), izoborneol (\%11.96-\%14.89), } \alpha \text {-pinen } \\
\text { (\%9.28-\%11.22), } \alpha \text {-terpineol (\%4.65-\%8.41) olarak tespit edilmiştir. Kampen (\%3.29-\%3.51), } \\
\text { limonen (\%2.89-\%3.61), p-simen (\%3.64-\%4.26) ve bornil asetat (\%2.02-\%3.13) yüksek oranlı } \\
\text { bileşenler olarak bulunmuştur. Çalışmanın sonucunda, biberiyenin uçucu yağ bileşenleri } \\
\text { miktarının mevsimlere göre önemli değişiklik gösterdiği ve kemotipinin } 1.8 \text { sineol olarak } \\
\text { belirlendiği tespit edilmiştir. }\end{array}$ \\
\hline
\end{tabular}




\section{INTRODUCTION}

The genus Rosmarinus belonging to the Lamiaceae family, includes two species, $R$. officinalis $\mathrm{L}$. and $R$. eriocalyx Jordan \& Fourr. $R$. officinalis known as rosemary. $R$. officinalis grows naturally in the Mediterranean regions such as Spain, Morocco, Tunisia, France, Italy and Turkey. Plants, including herbs and spices with an intense pleasent smell reminiscent of pine wood. The herb is economically important that cultivated or imported and sold in many markets all over the world. Rosemary is used fresh or dried. Its essential oil and herbs were widely used in folk medicine, cosmetics, phytocosmetics, flavouring and conservation of food products (Arnold et al., 1997; Pintone et al., 2002; Del Pilar SánchezCamargo and Herrero, 2017). The plant has antiinflammatory, chemopreventive, anti-cancer, antiproliferative, antimicrobial activities, protective towards neurological disorders. The rosemary tea used for decreasing the risks related to obesity, diabetes and metabolic syndrome (Del Pilar Sánchez-Camargo and Herrero, 2017). The oil of rosemary used in traditional medicine as a pulmonary antiseptic, a choleretic, a colagoguic and in cosmetic sector as soaps, perfumes, room sprays and deodorants. It has also stomachic, antidiarrhoic and antirheumatic properties (Arnold et al., 1997; Pintone et al., 2002; Özcan and Chalchat, 2008; Tawfeeq et al., 2016). Rosemary oil main components especially 1.8 cineole showed insecticidal effect on third instar larvae of the cabbage looper (Tak et al., 2016) and including other components as, camphor, $\alpha$-pinene or borneol have also been related to generally antioxidant and antimicrobial activities (Del Pilar Sánchez-Camargo and Herrero, 2017).

Rosemary oil can be distinguished with respect to two major types of main constituents: oils with over $40 \%$ of 1,8-cineole (Morocco, Tunisia, Turkey, Yugoslavia, Greece, Italy, France) and oils with approximately equal ratios (20-30\%) of 1.8-cineole, $\alpha$ pinene and camphor (Spain, France, Italy, Bulgaria, Greece). Generally, $\alpha$-pinene chemotypes are offen from Spain, bornyl acetate type from France, myrcene chemotype from Porteque and verbenone chemotype known from Eygpt (Tisserand and Young, 2012; Satyal et al., 2017). The external uses of rosemary are similarly numerous among the local people. In this study, the effect of seasonal variation on essential oil components of $R$. officinalis was detected by GC-MS.

\section{MATERIALS AND METHODS}

\section{Plant Material}

The herbs of rosemary were collected from Kahramanmaraş Sütçü İmam University Campus (altitude $530 \mathrm{~m}$ from sea level) between January and December, 2016. The average climatic values of the research year for Kahramanmaraş are given in Table 1 (Anonymous, 2016). The growing area of the plant is irrigated regularly in the summer. The soil structure of the campus area consists of clay, silt and sand (loamy soil) and average ph is 7.28 (Karagöktaş and Yakupoğlu, 2014). Plant materials were obtained in summer, autumn, winter and spring at different eleven months except for Agust. The flowering period was started early spring (March) and had flowers until autumn (end of October). Dried herba (leaves, flowers) of the plant $(30 \mathrm{~g})$ hydrodistilled for $3 \mathrm{~h}$ using a Clevenger type apparatus. Essential oil of the samples was analysed by GC-MS.

\section{GC-MS Analyses}

Analysis were conducted in the Plant Physiology Laboratory in Biology Dept. of KSU. Qualification of the oil was analyzed on an Agilent 5975C Mass Spectrometer coupled with Agilent GC-6890II series. The GC was equipped with HP-88 capillary column (100 m x $250 \mu \mathrm{m} \times 0.20 \mu \mathrm{m}$ film thickness) and flow rate of carrier gas was $1.0 \mathrm{~mL} / \mathrm{min}$. Oven temperature of GC was programmed as follows: $70{ }^{\circ} \mathrm{C}$ ( $\left.1 \mathrm{~min}\right), 230$ ${ }^{\circ} \mathrm{C}$ at of $10{ }^{\circ} \mathrm{C} / \mathrm{min}$ and then kept at $230^{\circ} \mathrm{C}$ at $20 \mathrm{~min}$. The injection part temperature was $250{ }^{\circ} \mathrm{C}$. The mass spectrometer was operating in El mode at $70 \mathrm{eV}$. Split ratio was $20: 1$. Mass range $35-400 \mathrm{~m} / \mathrm{z}$; scan speed (amu/s): $1000.10 \mu \mathrm{L}$ of the oil was shaked in $0.5 \mathrm{ml}$ diethyl ether and $1 \mu \mathrm{L}$ of the mixture injected into the column. The components were identified by mass spectra with those of pure authentic samples and Flavor2, Willey7n.1 and NIST98 libraries reference compounds. Retention indices were computed from gas chromatograms by logarithmic interpolation between $n$-alkanes. The homologous series of $n-$ alkanes C7-C40, Supelco, USA were used as standard. Retention indices calculated as HP-88 capillary column. All samples were repeated three times for GC/MS analysis.

\section{Statistical Analysis}

The main components statistical analyses were performed using SPSS 15.0 programme with WallerDuncen Test. 
Table 1. Mean temperature and total precipitation values of Kahramanmaraş 2016.

Çizelge 1. Kahramanmaraş 2016 yılına ait ortalama sıcaklık ve toplam yağış değerleri

\begin{tabular}{|c|c|c|c|c|c|c|c|c|c|c|c|}
\hline & \multicolumn{2}{|c|}{ Summer } & \multicolumn{3}{|c|}{ Autumn } & \multicolumn{3}{|c|}{ Winter } & \multicolumn{3}{|c|}{ Spring } \\
\hline & $J$ & J & $S$ & O & $\mathrm{N}$ & $\mathrm{D}$ & $J$ & $\mathrm{~F}$ & M & A & M \\
\hline Temp. $\mathrm{C}^{\circ}$ & 26.7 & 30.0 & 24.8 & 20.5 & 11.2 & 4.5 & 4.00 & 11 & 12.8 & 19.3 & 20.6 \\
\hline Precip. mm & 17.8 & 0.00 & 29.3 & 13.6 & 38.3 & 146.6 & 140.5 & 30.1 & 61.3 & 17.6 & 18.1 \\
\hline
\end{tabular}

\section{RESULTS AND DISCUSSION}

The essential oil composition of rosemary herba according to seasons and GC-MS chromatogram of main components were given in Table 2 and Figure 1, respectively. The major compounds were found as $\alpha$ pinene, 1.8-cineole, $\alpha$-terpineol, isoborneol and shown on the chromatogram as $1,2,3,4$, respectively (Figure 1). As the results of GC-MS, $97.68 \%, 98.60 \%$, $96.98 \%, 96.48 \%$ of the volatile components identified in rosemary essential oil from summer to spring. Rosemary oil was also dominated by monoterpenoids, especially oxygenated monoterpenes such as 1.8 cineole, $\alpha$-terpineol, isoborneol. Only, $\beta$-caryophyllene and caryophyllene oxide found as sesquiterpenes.

Major compounds statistical analysis according to seasons were given in Figure 2. Seasonal variations showed significant differences as statistically $(P<0.01)$. The main components 1.8 cineole and $\alpha$-pinene were increased with starting of hot temperature at spring and autumn while $\alpha$-terpineole and isoborneol were decreased.

Many studies about $R$. officinalis growing in Turkey have been conducted so firstly we discussed similar climatic locations with Kahramanmaraş province. Çeliktaş et al. (2007) analysed the essential oil composition from Mersin location at four different seasons and main components were found as 1.8 cineole with highest percentage (61.4\%, 60.9\%, 50.7\%, $58.1 \%)$ and $\alpha$-pinene contents were moderately high (10.2\%, 7.8\%, 9.4\% and 8.8\%) at December, March, June and September, respectively. Gülbaba et al. (2002) determined the rosmary chemotypes as 1.8 cineole $(41.7 \%-56.4 \%, 54.3 \%-44.4 \%$, 48.2\%-55.6\% at April, July, October, respectively) distributed between Adana-Mersin locations. Our findings shown similarity to Çeliktaş et al. (2007) and Gülbaba ve ark. (2002) reports. Özcan and Chalchat (2008), determined the main components of rosemary as p-cymene (44.02\%), linalool (20.5\%), $\gamma$-terpinene (16.62\%), in May from Mersin. Başkaya et al. (2016) determined the essential oil composition of $R$. officinalis at three vegetative period and found the main components as borneol (12.69\%-20.45\%), 1.8 cineole (15.82\%-17.93\%) and phor (11.50\%-14.36\%) at Hatay province. Kırpık (2005), determined the volatile compounds of 15 genotype $R$. officinalis growing in Çukurova dryland and highland conditions and main components ( $\alpha$-pinen, camphen, myrcene, cymol, limonene, 1.8 cineole, campher, borneol) were shown differences according to genotype. As the studies according to different geographical region from Turkey, Topal et al. (2008) determined the main components as b- camphor (12.94\%) and borneol (14.21\%), Orhan et al. (2008) found as 1,8-cineole (44.42\%) chemotype from Balıkesir province and Gürbüz et al. (2016) determined the chemotype of rosmary collected from İzmir, Aydin, Antalya, Mersin, Adana and Hatay but growing in Ankara ecologic conditions. Mersin and İzmir genotype determined as 1.8 cineole but the others camphor. Çeliktaş et al. (2007) studied differences of chemical compounds of rosemary according to seasons from Çanakkale and İzmir beside Mersin location, reffered above. The main component 1.8 cineole content was found higher in İzmir than Çanakkale and Çanakkale oils were richer about camphor and verbonene.

The studies about $R$. officinalis essential oil from other countries; 1.8-cineole chemotype detected from Grecee, Morocco, UK (Papageorgiou et al., 2008; AitOuazzou et al., 2011; Tawfeeq et al., 2016), camphor chemotype reported from İtaly, Spain and Brazil (Arnold et al., 1999; Porte et al., 2000) and $\alpha$-pinene chemotype determined from Lebanon, Italy, Iran (Diab et al., 2002; Pintore et al., 2002; Jamshidi et al., 2009). Jordan et al. (2013), collected 150 rosmary plant from different bioclimatic zones at Spain and determined the chemotypes as 1.8-cineole, camphor and $\alpha$-pinene type and were not shown statistically significant differences between the zones. Diab et al. (2002) detected that main component $\alpha$-pinene was reached maximum level at flowering period. Papageorgiou et al. (2008) investigated the differences of chemical composition and observed that the highest component 1.8 -cineole (50.6\%-58.7\%) had been in higher amount at May and Agust than February. These findings were supported our results. 
Table 2. Chemical composition of $R$. officinalis herba according to seasons.

Çizelge 2. R. officinalis toprak üstü kısımlarının mevsimlere göre kimyasal kompozisyonu.

\begin{tabular}{|c|c|c|c|c|c|c|}
\hline Components & RT & $\mathbf{R I}$ & Summer & Autumn & Winter & Spring \\
\hline$\alpha$-pinene & 10.81 & 1012 & 11.22 & 9.55 & 9.28 & 9.87 \\
\hline camphene & 11.26 & 1085 & 3.39 & 3.33 & 3.29 & 3.51 \\
\hline$\beta$-pinene & 11.57 & 1126 & 1.72 & 2.05 & 2.78 & 2.82 \\
\hline myrcene & 11.69 & 1141 & 1.21 & 1.18 & 1.18 & 1.18 \\
\hline$\alpha$-phellandrene & 11.90 & 1166 & 0.18 & 0.13 & 0.13 & 0.15 \\
\hline limonene & 12.09 & 1188 & 3.61 & 3.17 & 2.89 & 3.09 \\
\hline ocimene & 12.29 & 1210 & 0.38 & 0.24 & 0.29 & 0.31 \\
\hline sabinene & 12.50 & 1231 & 0.92 & 0.72 & 0.93 & 1.02 \\
\hline 1.8 cineole & 12.98 & 1278 & 43.61 & 44.54 & 41.25 & 45.96 \\
\hline p-cymene & 13.27 & 1305 & 4.19 & 4.26 & 3.64 & 3.67 \\
\hline 1-octen-3-ol & 14.71 & 1427 & 1.60 & 0.68 & 0.64 & 0.65 \\
\hline linalol & 15.79 & 1430 & 1.14 & 1.3 & 1.01 & 1.35 \\
\hline$\beta$-caryophyllene & 16.53 & 1582 & 0.75 & 0.50 & 1.14 & 0.87 \\
\hline fenchyl alcohol & 16.82 & 1606 & 0.27 & 0.28 & 0.35 & 0.27 \\
\hline bornyl acetate & 17.05 & 1626 & 3.13 & 2.02 & 2.95 & 3.13 \\
\hline exo-methyl-camphenilol & 17.40 & 1655 & 0.10 & 0.24 & 0.23 & 0.36 \\
\hline$\alpha$-terpineol & 17.90 & 1696 & 6.05 & 8.41 & 7.11 & 4.65 \\
\hline Isoborneol & 18.27 & 1730 & 13.00 & 14.52 & 14.89 & 11.96 \\
\hline myrtenal & 18.86 & 1781 & 0.16 & 0.17 & 0.10 & 0.10 \\
\hline cis-verbenol & 19.11 & 1803 & not found & 0.11 & 0.28 & 0.03 \\
\hline geranyl acetone & 19.66 & 1855 & 0.12 & 0.27 & 0.63 & 0.24 \\
\hline methyl eugenol & 21.47 & 1974 & not found & 0.19 & 0.20 & 0.13 \\
\hline benzothiazole & 21.82 & 1993 & 0.33 & 0.06 & 0.47 & 0.12 \\
\hline thymol & 21.94 & 1999 & 0.13 & 0.09 & 0.26 & 0.15 \\
\hline caryophyllene oxide & 22.20 & 2031 & 0.40 & 0.45 & 0.88 & 0.80 \\
\hline carvacrol & 22.64 & 2083 & 0.07 & 0.11 & 0.10 & 0.06 \\
\hline eugenol & 23.15 & 2147 & not found & 0.03 & 0.08 & 0.03 \\
\hline \multicolumn{3}{|l|}{ Total } & 97.68 & 98.60 & 96.98 & 96.48 \\
\hline \multicolumn{3}{|c|}{ Monoterpene hydrocarbons } & 26.82 & 24.63 & 24.41 & 25.62 \\
\hline \multicolumn{3}{|c|}{ Oxygenated monoterpenes } & 67.41 & 71.54 & 68.58 & 67.63 \\
\hline \multicolumn{3}{|c|}{ Sesquiterpene hydrocarbons } & 0.75 & 0.50 & 1.14 & 0.87 \\
\hline \multicolumn{3}{|c|}{ Oxygenated sesquiterpenes } & 0.40 & 0.45 & 0.88 & 0.80 \\
\hline \multicolumn{3}{|l|}{ Phenylpropanoids } & not found & 0.22 & 0.28 & 0.16 \\
\hline \multicolumn{3}{|l|}{ Others } & 2.30 & 1.26 & 1.69 & 1.40 \\
\hline
\end{tabular}

RT: Retention Time. RI: Retention Index.

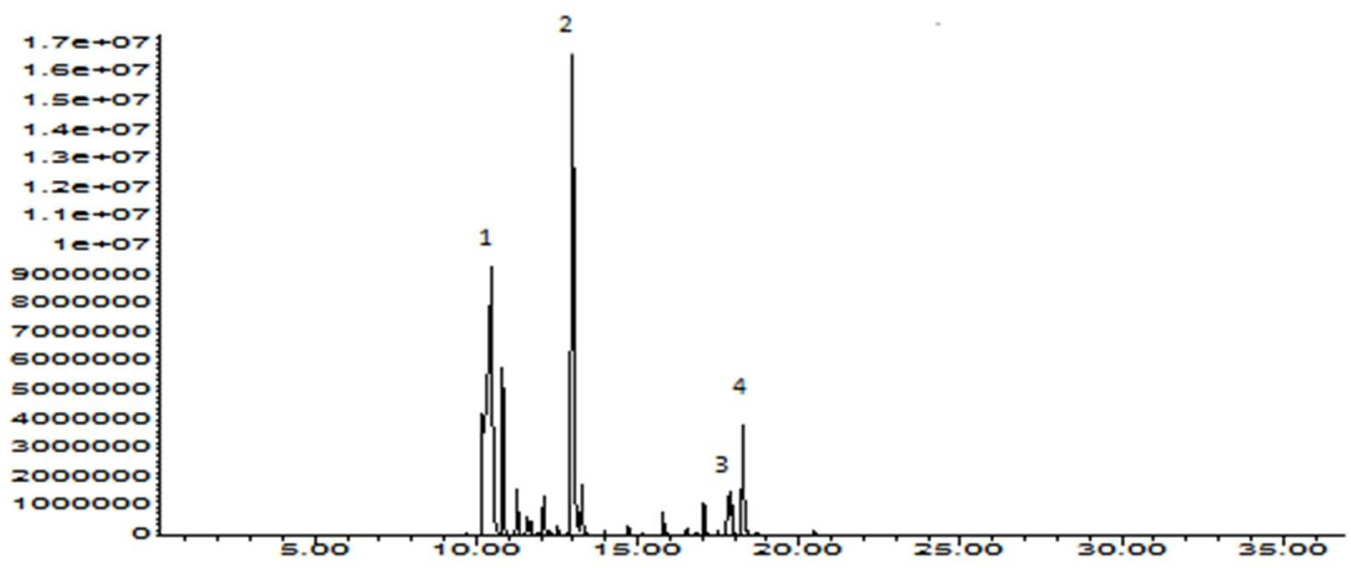

Figure 1. GC-MS chromatogram of $R$. officinalis essential oil.

Şekil 1. R. officinalis uçucu yağının GC-MS kromatogramı. 


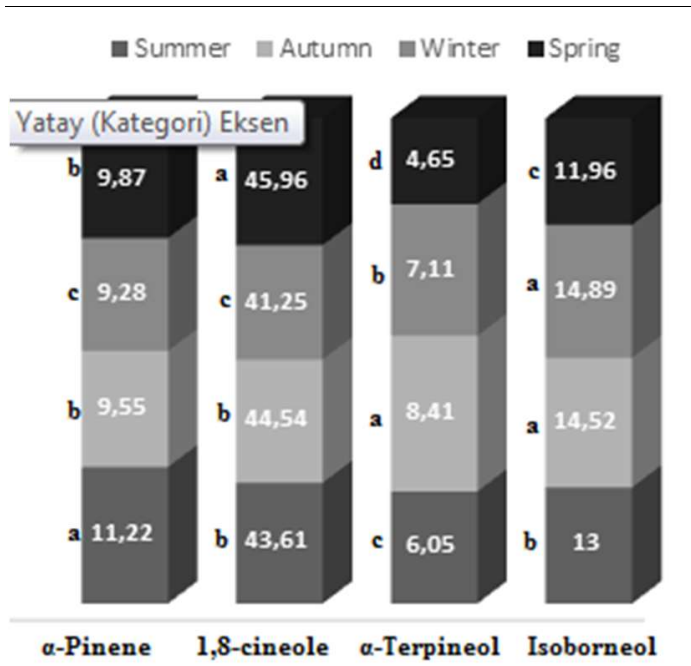

Figure 2. The percentage of the $R$. officinalis main components according to seasons.

Şekil 2. R. officinalis ana bileşenlerinin mevsimlere göre oranı.

\section{CONCLUSION}

To the best of our knowledge, this is first report about chemical composition of rosmary, growing in Kahramanmaraş province. As the result of this study, $R$. officinalis essential oil shown 1.8 cineole chemotype and the seasons affected the main components amount. This result confirmed the Tisserand and Young (2012) chemotype classification according to geographical region. As conclusion, we discussed the reports on essential oil composition of $R$. officinalis from different regions of the world and Turkey and the stuides were shown that 1.8-cineole, camphor, $\alpha$ pinene, camphene, bornyl acetate, $\alpha$-terpineol and verbenone were found as main components and these components amount was shown differences between the locations and different chemotypes could be seen in the same region.

Differences on the components and percent of the components may be affected from soil, climate, altitude and vegative period of the plant. In Turkey, rosemary growing at Adana-Mersin province preffered by customers. $R$. officinalis from Kahramanmaraş shown similar chemotype with Adana-Mersin samples. As a result, $R$. officinalis can be grown in these area and preffered to harvest at spring for high 1.8 cineole content.

\section{REFERENCES}

Ait-Ouazzou A., Lorán S., Bakkali M., Laglaoui A., Rota C., Herrera A., Pagan R and Conchello P., 2011. Chemical composition and antimicrobial activity of essential oils of Thymus algeriensis, Eucalyptus globulus and Rosmarinus officinalis from Morocco. Journal of the Science of Food and Agriculture, 91: 2643-2651.
Anonymous 2016. Kahramanmaraş Meteoroloji İstasyonu Verileri.

Arnold N., Valentini G., Bellomaria B and Hocine L., 1997. Comparative study of the essential oils from Rosmarinus eriocalyx Jordan \& Fourr. from Algeria and $R$. officinalis $\mathrm{L}$. from other countries. Journal of Essential Oil Research, 9: 167-175.

Başkaya Ş., Ayanoğlu F ve Bahadırlı NP., 2016. Biberiye (Rosmarinus officinalis L.) bitkisinin uçucu yağ oranı, uçucu yağ bileşenleri ve antioksidan içeriğinde morfogenetik ve ontogenetik varyabilite. Mustafa Kemal Üniversitesi Ziraat Fakültesi Dergisi, 21:12-20.

Celiktas OY., Kocabas EH., Bedir E., Sukan FV., Ozek T and Baser KHC., 2007. Antimicrobial activities of methanol extracts and essential oils of Rosmarinus officinalis, depending on location and seasonal variations. Food Chemistry, 100: 553-559.

Del Pilar Sánchez-Camargo A and Herrero M., 2017. Rosemary (Rosmarinus officinalis) as a functional ingredient: recent scientific evidence. Current Opinion in Food Science, 14: 13-19.

Diab Y., Auezova L., Chebib H., Chalchat JC and Figueredo G., 2002. Chemical composition of Lebanese rosemary (Rosmarinus officinalis L.) essential oil as a function of the geographical region and the harvest time. Journal of Essential Oil Research, 14: 449-452.

Gülbaba AG., Özkurt N., Kürkçüoğlu M ve Başer KHC., 2002. Mersin ve Adana yöresindeki doğal biberiye (Rosmarinus officinalis L.) populasyonlarının tespiti ve uçucu yağ verim ve bileşimlerinin belirlenmesi. Orman Bakanlığı Teknik Bülten, 193: 5-30.

Gürbüz B., Bağdat RB., Uyanik M and Rezaeieh KAP., 2016. Rosemary (Rosmarinus officinalis L.) cultivation studies under Ankara ecological conditions. Industrial Crops and Products, 88: 12-16.

Jamshidi R., Afzali Z and Afzali D., 2009. Chemical composition of hydrodistillation essential oil of rosemary in different origins in Iran and comparison with other countries. American-Eurasian Journal of Agricultural \& Environmental Sciences, 5: 78-81.

Jordán MJ., Lax V., Rota MC., Lorán S and Sotomayor JA., 2013. Effect of bioclimatic area on the essential oil composition and antibacterial activity of Rosmarinus officinalis L. Food Control, 30: 463-468.

Karagöktaş D and Yakupoğlu T., 2014. Erozyon araştırma sahasına dönüştürülmesi planlanan bir alanda aşınabilirlik ve toprak özellikleri arasındaki ilişkiler. Toprak Bilimi ve Bitki Besleme Dergisi, 2: 6-12.

Kirpik M., 2005. Evaluating qualitative rosemary (Rosmarinus officinalis L.) lines growing in arid soils of cukurova region. Doctoral dissertation, Ph. D. thesis, Cukurova University Institute of Science, Adana. 
Orhan I., Aslan S., Kartal M., Şener B and Başer KHC., 2008. Inhibitory effect of Turkish Rosmarinus officinalis $\mathrm{L}$. on acetylcholinesterase and butyrylcholinesterase enzymes. Food Chemistry, 108: 663-668.

Özcan MM and Chalchat JC., 2008. Chemical composition and antifungal activity of rosemary (Rosmarinus officinalis L.) oil from Turkey. International Journal of Food Sciences and Nutrition, 59: 691-698.

Papageorgiou V., Gardeli C., Mallouchos A., Papaioannou M and Komaitis M., 2008. Variation of the chemical profile and antioxidant behavior of Rosmarinus officinalis L. and Salvia fruticosa Miller grown in Greece. Journal of Agricultural and Food Chemistry, 56: 7254-7264.

Pintore G., Usai M., Bradesi P., Juliano C., Boatto G., Tomi F and Casanova J., 2002. Chemical composition and antimicrobial activity of Rosmarinus officinalis L. oils from Sardinia and Corsica. Flavour and Fragrance Journal, 17: 15-19.

Porte A., Godoy RIdo, Lopes D., Koketsu M., Gonçalves S and Torquilho HS., 2000. Essential oil of Rosmarinus officinalis L. (rosemary) from Rio de Janeiro, Brazil. Journal of Essential Oil Research, 12: 577-580.
Satyal P., Jones TH., Lopez EM., McFeeters RL., Ali NAA., Mansi I and Setzer WN., 2017. Chemotypic characterization and biological activity of Rosmarinus officinalis. Foods, 6: 2-15.

Tak JH., Jovel E and Isman MB., 2016. Comparative and synergistic activity of Rosmarinus officinalis L. essential oil constituents against the larvae and an ovarian cell line of the cabbage looper, Trichoplusia ni (Lepidoptera: Noctuidae). Pest Management Science, 72: 474-480.

Tawfeeq A., Culham A., Davis F., Reeves M and Michael N., 2016. The influence of genetic variation on essential oil composition in Rosmarinus officinalis L. the common rosemary. 9th Joint Natural Products Conference, 24-27 July, Copenhagen, Denmark.

Tisserand R and Young R., 2012. Essential Oil Safety. Churchill Livingstone Elsevier $2^{\text {nd }}$ Edition, China.

Topal U., Sasaki M., Goto M and Otles S., 2008. Chemical compositions and antioxidant properties of essential oils from nine species of Turkish plants obtained by supercritical carbon dioxide extraction and steam distillation. International Journal of Food Sciences and Nutrition, 5: 619-634. 